\title{
ВЛИЯНИЕ НЕСЬЕМНЫХ ОРТОПЕДИЧЕСКИХ КОНСТРУКЦИЙ НА ЗДОРОВЬЕ ПАРОДОНТА
}

\section{IMPACT OF NON-REMOVABLE ORTHOPEDIC DEVICES EFFECTS ON PERIODONTAL HEALTH}

\author{
A. Belousova \\ G. Emelina \\ S. Smolyaninov \\ A. Nikonova \\ E. Emelina
}

Summary. The quality of non-removable dentures depends simultaneously on the restoration of lost functions of the oral cavity, the creation of aesthetics and compliance with manufacturing technology. When trying to achieve the maximum aesthetic effect and strength of prostheses, the requirements for the quality of hygienic procedures of orthopedic structures are often not taken into account. The purpose of this study was to review the literature on the biological and aesthetic characteristics of materials used for fixed structures over the past 15 years. The literature review was conducted in MEDLINE (via PubMed), the Wiley online library, and ProQuest databases from 2005 to 2019. Articles describing fixed dentures and their impact on periodontal tissues, peri-implant tissues, and aesthetics were reviewed.

Keywords: implant, crown, fixed prosthesis, aesthetics, CAD/CAM.
Белоусова Анна Вячеславовна ФГБОУВО «Пензенский государственный университет» anbel988@mail.ru

Емелина Галина Владимировна

К.м.н., дочент, ФГБОУВО «Пензенский государственный университет» sto.emelina@yandex.ru Смольянинов Сергей Иванович Cm. nреподаватель, ФГБОУВО «Пензенский государственный университет» smolyeninov@mail.ru

Никонова Анна Валерьевна Ассистент, ФГБОУ ВО «Пензенский государственный университет»

stomannavaleryevna@mail.ru

Емелина Елена Сергеевна

Ассистент, Первый МГМУ им. И. М. Сеченова (Сеченовский университет) (Москва) lenaaemelina@mail.ru

Аннотация. Качество несъемных протезов зависит одновременно от восстановления утраченных функций полости рта, создания эстетики и соблюдения технологии изготовления. При попытке добиться максимального эстетического эффекта и прочности протезов часто не учитываются требования к качеству проведения гигиенических процедур ортопедических конструкций. Целью этого исследования был обзор литературы, касающийся биологических и эстетических характеристик материалов, используемых для несъемных конструкций за последнее 15 лет. 0бзор литературы проводился в MEDLINE (через PubMed), онлайн-библиотеке Wiley, в базах данных ProQuest за период с 2005 по 2019 год. Были рассмотрены статьи, в которых описывались несъемные зубные протезы и их влияние на ткани пародонта, периимплантатные ткани и эстетику.

Ключевые слова: имплант, коронка, несъемный протез, эстетика, CAD/CAM.
4 астота биологических осложнений, возникающих в процессе ортопедического лечения несъемными конструкциями, отмеченных в литературе, составляет $0,6 \%$ для одной коронки и 4\% для мостовидных протезов [8], а частота воспаления периимплантной ткани колеблется от 60 до 80\% (3). В литературе сообщается, что после 5 лет функционирования несъемные протезы с опорой на имплантаты демонстрируют 8,5\% биологических осложнений, одиночные коронки - 7,1\% биологических осложнений и 7,1\% эстетических осложнений [11]. В последнее время требования к стоматологическим услугам значительно возросли, требуется обеспе- чить эстетическое и функциональное единство, качество проведения гигиенических процедур ортопедических конструкций и здоровье полости рта. По мимо этого, наблюдается бурное развитие материаловедения и технологий, начиная от ручного изготовления каркасов до CAD/CAM [6]. Приоритеты имплантологии изменились, например, остеоинтеграция, обеспечиваемая многими факторами, стала необходима для стабильности имплантата [14]. Важным этиологическим аспектом воспаления в тканях пародонта является наличие бактерий, на наличие которых влияет иммунный ответ организма [15]. Риск заболеваемости повышается, если ортопеди- 
ческая конструкция вызывает прямое механическое повреждение тканей, ускоряет прикрепление зубного налета и препятствует возможности самоочищения зубных протезов в полости рта [2,10]. Воспаление начинается как мукозит/гингивит и при недостаточном уходе переходит в пародонтит/периимплантит [10]. Для снижения риска возникновения осложнений важны знания, технические навыки, правильное планирование лечения, взаимодействие врача и зубного техника [3,4]. Внимание специалистов, участвующих в этом процессе, должно быть обращено на своевременное выявление существующих проблем с целью их уменьшения и предотвращения [1,7]. Для обеспечения функции протезов, эстетики, гигиены и механической стабильности одновременно должны соблюдаться следующие факторы: анатомическая форма подготовленной коронки, точность расположения края коронки и прилегания к десневому краю, место и тип соединения имплантата с абатментом, тип изготовления абатмента, тип фиксации коронки на имплантате, а также применяемый материал [16].

Чтобы узнать предварительные результаты использования фиксированных полных протезов с опорой на импланты, Вайнштейном и соавт. было проведено клиническое исследование [18]. Каждому пациенту $(\mathrm{n}=20)$ установили по четыре имплантата и акриловый временный протез, а через 4-6 месяцев был изготовлен и установлен постоянный протез, изготовленный с помощью CAD/CAM. Каждые 6 месяцев в течение первых 2-х лет и затем ежегодно в течение 5 лет во время последующих визитов с помощью опросов оценивались: рентгенограммы (маргинальный уровень кости - 0,6 $00,3 / 0,7 \pm 0,4)$, индекс бляшки $(8,1 \pm 6,0 \%$ через

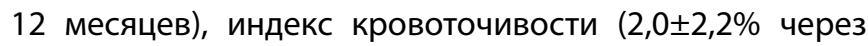
12 месяцев), удовлетворенность пациентов функцией (77,8\% и $88,9 \%$ - отлично или очень хорошо) и эстетикой (66,7\% отлично или очень хорошо) [18].

Значительно большие горизонтальные и вертикальные дефекты на вестибулярных поверхностях имплантата наблюдались в исследовании, проведённом Huynh-Ba и др, оно проводилось в группе сразу же установленных имплантатов в течение 3 месяцев [9]. Оценивая эстетику и клинические показатели, Migliorati и др. обнаружили статистически значимые различия между группами с аугментацией мягких тканей $(66,6 \%)$ и без аугментации мягких тканей (17,3\%) [12]. В группе с аугментацией наблюдались увеличение толщины ороговевшей слизистой оболочки на 34,29\% (0,5 мм) и рецессии - на 10,01\% от исходной высоты (0,02 мм). Толстый биотип пародонта показал незначительную усадку и рецессию мягких тканей по сравнению с тонким биотипом. Payer и др. обнаружили различия в результатах оценки между циркониевыми и титановыми имплантатами (циркониевые имплантаты - 11,22 ( $\pm 1,56)$, титановые имплантаты соответственно $10,75( \pm 0,7)$ [ [13]. Рентгенологическая оценка выявила значительную потерю костной массы в течение 24 месяцев в обеих группах имплантатов (цирконий от 0,67 мм до 1,48 мм, титан от 0,16 мм до 1,43 мм) [5,13]. Оценка, проведенная Santing и др, подтвердила рецессию десны, которая произошла в течение первых 7 месяцев после установки имплантата, но объем десневого сосочка увеличился в период с 7 до 18 месяцев [17]. Наблюдается тенденция к улучшению эстетики мягких тканей у циркониевых абатментов, оценка признаков воспаления вокруг мягких тканей не выявила никаких биологических осложнений [13]. Более высокие значения показателей биологических осложнений были обнаружены у имплантатов, по сравнению с соседними зубами, но они были все еще в пределах низкого уровня [12]. Измерения проводились в разные временные точки: через 3 месяца, 1 год, 18 месяцев, 2 года, 3 года и 7,5 лет [13].

Имплантаты CAD/CAM, абатменты, каркасы для коронок и мостовидных протезов демонстрируют клинически приемлемые результаты в полости рта с высокой удовлетворенностью пациентов в течение одного-трех лет. При улучшении эстетики здоровье мягких тканей должно быть принято в качестве приоритета. Целесообразно использовать материалы для протезов с более низкой вероятностью адгезии бактериальных бляшек и лучшими полирующими свойствами (цирконий, керамика, металл).

Исходя из вышеизложенного, нет никаких доказательств того, что ортопедическая конструкция увеличивает воспаление мягких тканей, однако взаимосвязь между эстетикой и здоровьем мягких тканей при установке имплантатов, коронок и протезов остается актуальной темой для будущих исследований.

\section{ЛИТЕРАТУРА}

1. Акопян Г.В., Хачатрян А. Г. Ретроспективный анализ влияния заболеваний пародонта на приживление имплантатов и долгосрочный прогноз проведенной имплантации. Пародонтология. 2011. Т. 16. № 1 (58). С. 39-43.

2. Балахничев Д.Н., Шторина Г. Б., Соснина Ю. С. Влияние несъемных ортопедических конструкций на пародонт опорных зубов. Пародонтология. 2011. Т. 16. № 1 (58). C. 8-10.

3. Кулыгин О. Б. Состояние гигиены полости рта и тканей пародонта, биофизические и биохимические показатели обследования больных с неудовлетворительными результатами лечения дефектов боковой группы зубов мостовидными протезами. Вестник стоматологии. 2009. № 1 (66). С. 11-20. 
4. Ожоган 3.Р., Обидняк В. З., Мизюк Л. В., Панченко В. И. Современные методы гигиены полости рта у пациентов с несъемными конструкциями протезов. Современная стоматология. 2016. № 5 (84). С. 66.

5. Проволукин Н.В., Малюченко А.С., Сандулеев М.А., Алексеев Н. Ю. Оценка состояния тканей пародонта при использовании имплантов из диоксида циркония и титана. В сборнике: Актуальные вопросы и перспективы развития медицины. сборник научных трудов по итогам III международной научно-практической конференции. 2016. С. 151-153.

6. Abdulmajeed A.A., Lim K. G., Närhi T. 0., Cooper L. F. Completearch implant-supported monolithic zirconia fixed dental prostheses: A systematic review. J Prosthet Dent. 2016; 115:672-7.

7. De Backer H., Van Maele G., De Moor N., Van den Berghe L. Survival of complete crowns and periodontal health: 18-year retrospective study. Int J Prosthodont. 2007; 20:151-8.

8. Goodacre C.J., Bernal G., Rungcharassaeng K., Kan J.Y. Clinical complications in fixed prosthodontics. J Prosthet Dent 2003; 90:31-41.

9. Huynh-Ba G., Meister D. J., Hoders A. B., Mealey B. L., Mills M. P., Oates T.W., et al. Esthetic, clinical and patient-centered outcomes of immediately placed implants (Type 1) and early placed implants (Type 2): preliminary 3-month results of an ongoing randomized controlled clinical trial. Clin Implant Dent Relat Res 2016; 27:241-52.

10. Ikai H., Kanno T., Kimura K., Sasaki K. A retrospective study of ¿xed dental prostheses without regular maintenance. J Prosthodont Res. 2010;54:173-8.

11. Jung R.E., Zembic A., Pjetursson B.E., Zwahlen M., Thoma D. S. Systematic review of the survival rate and the incidence of biological, technical, and aesthetic complications of single crowns on implants reported in longitudinal studies with a mean follow-up of 5 years. Clin Oral Implants Res. 2012; 23:2-21.

12. Migliorati M., Amorini L., Signori A., Biavati A.S., Benedicenti S. Clinical and Aesthetic Outcome with Post-Extractive Implants with or without soft tissue augmentation: A 2-year randomized clinical trial. Clin Implant Dent Relat Res 2015; 17:983-95.

13. Payer M., Heschl A., Koller M., Arnetzl G., Lorenzoni M., Jakse N. All-ceramic restoration of zirconia two-piece implants — a randomized controlled clinical trial. Clin Oral Implants Res $2015 ; 26: 371-76$.

14. Pesce P., Menini M., Tealdo T., Bevilacqua M., Pera F., Pera P. Peri-implantitis: a systematic review of recently published papers. Int J Prosthodont. 2014; 27:15-25.

15. Renvert S., Persson G. R. Periodontitis as a potential risk factor for peri-implantitis. J Clin Periodontol. 2009; 36:9-14.

16. Rodriguez A.M., Rosenstiel S. F. Esthetic considerations related to bone and soft tissue maintenance and development around dental implants: report of the Committee on research in fixed prosthodontics of the American Academy of fixed prosthodontics. J Prosthet Dent 2012; 108:259-67.

17. Santing H.J., Raghoebar G. M., Vissink A., den Hartog L., Meijer H. J. Performance of the Straumann Bone Level Implant system for anterior single-tooth replacements in augmented and nonaugmented sites: a prospective cohort study with 60 consecutive patients. Clin Oral Implants Res 2013; 24:941-8.

18. Weinstein R., Agliardi E., Fabbro M. D., Romeo D., Francetti L. Immediate rehabilitation of the extremely atrophic mandible with fixed full-prosthesis supported by four implants. Clin Implant Dent Relat Res 2012; 14:434-41.

(c Белоусова Анна Вячеславовна ( anbel988@mail.ru ), Емелина Галина Владимировна ( sto.emelina@yandex.ru ),

Смольянинов Сергей Иванович ( smolyeninov@mail.ru ), Никонова Анна Валерьевна ( stomannavaleryevna@mail.ru),

Емелина Елена Сергеевна ( lenaaemelina@mail.ru ).

Журнал «Современная наука: актуальные проблемы теории и практики»

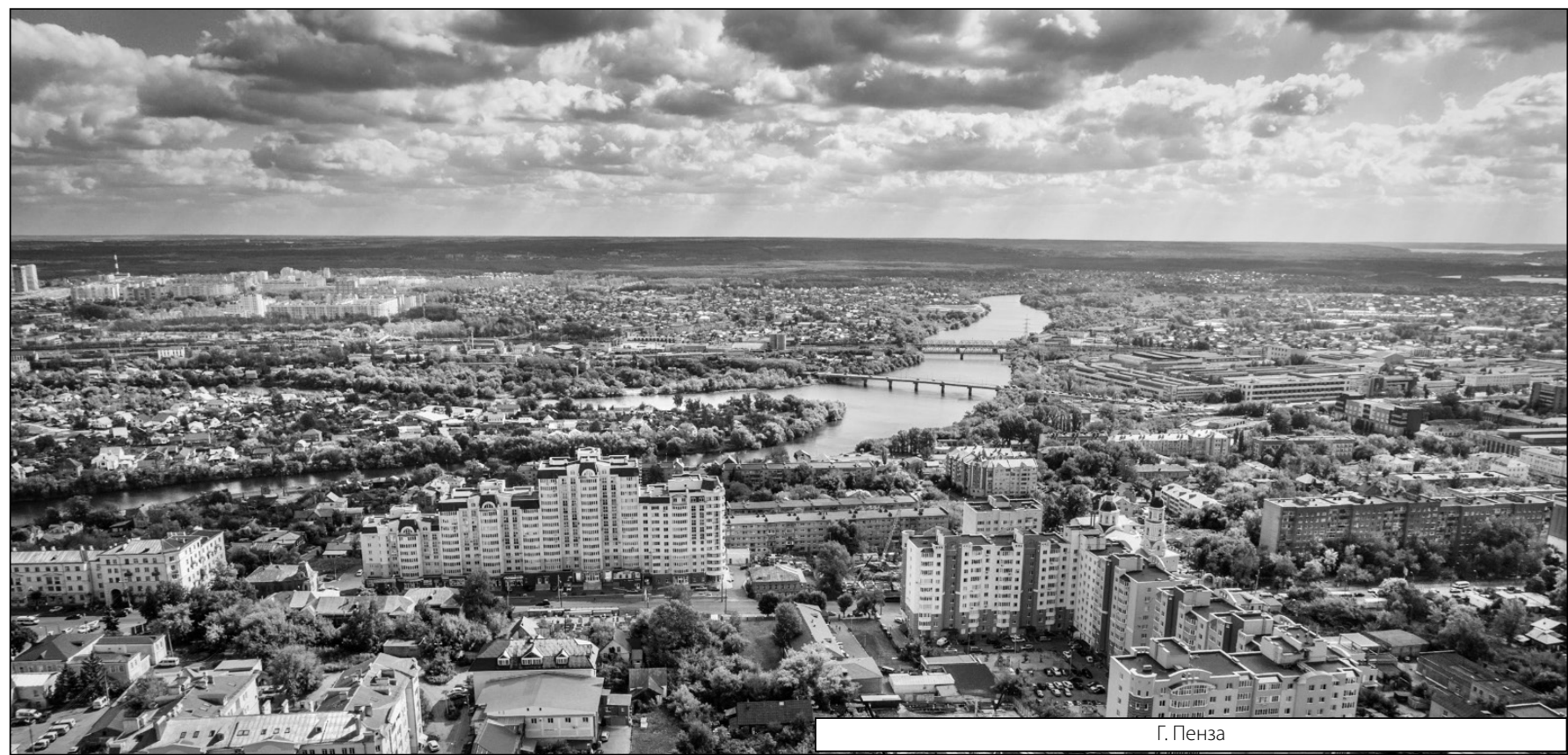

